\title{
COCONUT HUSK AS A BATIK COLORING MATERIAL
}

\author{
Yogi Setiawan', Sri Wiratma² \\ 1Fakultas Bahasa Dan Seni, Universitas Negeri Medan \\ 2Universitas Indonesia \\ e-mail : setiawan.y10@yahoo.com \\ wiratma6o@yahoo.com
}

\begin{abstract}
Abstrak
Penelitian ini bertujuan untuk mendeskripsikan bagaimana proses pembuatan warna batik berbahan sabut kalapa dan menganalisis hasil dari pewarnaan batik berbahan sabut kelapa. Dalam metode penelitian untuk mengetahui bagaimana pengaruh lama dalam perendaman larutan warna yang akan dapat menghasilkan warna dan juga mengetahui bagaimana proses pembuatan warna tersebut, peneliti menggunakan metode penelitian Kualitatif Deskriptif. Setelah dilakukan pengumpulan data melalui instrumen penelitian observasi, wawancara dan dokumentasi. Pembuatan warna alami pada batik harus dengan teliti dan benar, hasil penelitian menunjukkan bahwa pada proses sangat berpengaruh pada hasil akhirnya. Hasil yang diperoleh pada interval waktu 5 jam, 10 jam, 15 jam dan yang dicelup kering berulang-ulang sebanyak 7 kali pencelupan, menjadi perbedaan warna yang tidak begitu begitu berpengaruh pada hasil yang di dapatkan, peneliti menyimpulkan jika kain direndam dalam larutan warna 10 jam keatas itu akan menjadi hasil yang sama saja, berdasarkan kepekatan warna yang akan didapatkan. Warna yang dihasilkan dari ekstrak sabut kelapa pada Fiksasi tawas menjadi warna coklat terang, kemudian pada Fiksasi tunjung menjadi coklat tua dan pada Fiksasi kapur menjadi coklat kekuningan.
\end{abstract}

kata kunci: pewarnaan; sabut kelapa; fiksasi.

\begin{abstract}
This study aims to describe how the process of making the color of batik made from coconut husk and to analyze the results of coloring batik made from coconut husk. In the research method to find out how the long effect of immersion in the color solution which will be able to produce color and also find out how the process of making the color is, researchers used descriptive qualitative research methods. After collecting data through observation research instruments, interviews and documentation. The making of natural colors in batik must be meticulous and correct, the results of the research show that the process is very influential on the final result. The results obtained at intervals of 5 hours, 10 hours, 15 hours and those that were dyed dry repeatedly for 7 times of dyeing, became a color difference that did not really affect the results obtained, the researchers concluded if the cloth was soaked in a 10 hour color solution. and above it will be the same result, based on the density of the color that will be obtained. The color produced from the coconut husk extract on the fixation of alum becomes light brown, then on the fixation it turns dark brown and on the fixation of lime it becomes yellowish brown.
\end{abstract}

keywords: coloring,; coconut coir; fixation.

\section{PENDAHULUAN}

Batik merupakan hasil budaya warisan nenek moyang yang harus dijaga dengan baik dan benar. UNESCO telah mengakui bahwa keseluruhan teknik, teknologi, serta pengembangan motif dan budaya yang terkait telah ditetapkan sebagai warisan kemanusiaan untuk budaya sejak 2 Oktober 2009.
Batik memiliki nilai seni yang sangat tinggi dilihat dari pembuatannya, makna dan nilai filosofi yang terkandung pada motif batik memiliki alur cerita didalamnya, Kerajinan batik pada mulanya merupakan tradisi turun temurun hingga pada saat ini batik bisa dinikmati oleh banyak orang.

Ciri-ciri batik ada dua yakni batik tradisional dan batik modern, batik tradisional 
memiliki nilai dan makna simbolik pada setiap motifnya sementara batik moderen cenderung bebas dan tidak memiliki makna secara khusus begitu juga dengan warna yang digunakan pada batik modern cenderung lebih bebas. Proses pembuatan batik juga beragam yang tidak semua orang tau, diantaranya batik tulis, batik cap dan batik printing.

Pewarnaan batik ada yang berbahan sintetik (pewarna kimia) dan pewarna yang menggunakan bahan-bahan alami, Pewarna alami adalah pewarna yang berasal dari alam dan diproses secara sederhana, hanya saja proses pembuatannya memakan waktu yang cukup panjang akan tetapi ramah pada lingkungan tidak seperti pewarna sintetik (pewarna kimia) tidak ramah pada lingkungan.

Penggunaan pewarna batik alami menjadi solusi untuk menguranginya dampak negatif dari limbah yang ada. Penggunaan pewarna batik alami lebih ramah akan lingkungan, mudah untuk dicari dan sekaligus dapat memberikan pengetahuan wawasan tersendiri kepada pengrajin batik. Tentunnya jika menggunakan pewarna alami akan lebih menguntungkan, tidak hanya untuk pelaku perajin batik akan tetapi pada semua orang.

Bahan pewarna alami bisa diolah dari tumbuh-tumbuhan seperti akar pohon, batang pohon, kulit kayu, ranting, daun, bunga dan buah. semuanya bisa dibuat menjadi bahan pewarna alam, akan tetapi tidak semua tanaman bisa dijadikan pewarna alami untuk tekstil.

Pada proses pembuatanya memakan waktu yang cukup panjang, dimulain dari pencarian bahan, perebusan, sampai hasil dari ekstrak dari bahan alami tersebut. Warna yang akan didapatpun menjadi variasi, jika menerapkan waktu yang berbeda akan menghasilkan warna yang berbeda dan jika menggunakan Fiksasi yang berbeda akan menghasilkan warna yang berbeda pula, dan yang menjadi kelemahan dari warna alami adalah tidak secerah warna berbahan kimia.

\section{KAJIAN TEORI}

\section{Warna}

Pemahaman teori warna ini sudah berkembang lama, yang dikaji dari sudut pandang ilmu pengetahuan Psikis dan Estetika. Isaac Newton seorang Fisikawan yang telah mengkaji teori Optik yang kemudian menghasilkan penemuannnya mengenai refraksi cahaya menggunakan prisma kaca segitiga yang menhasilkan warna.

Warna merupakan salah satu daya tarik utama, dan merupakan kriteria paling penting untuk penerimaan produk seperti tekstil, zat warna sangat diperlukan untuk menembah nilai artistik dalam memvariasikan suatu produk.

Pewarna alami merupakan pewarna yang berasal dari zat warna yang terdapat pada tumbuh-tumbuhan. Pewarna alami sudah digunakan pada zaman dahulu untuk mewarnai benang dan kain yang berasal dari serat alam.

Dalam keadaan saat ini sering sekali dijumpai bahan pewarna sintetik digunakan dibandingkan barbahan alami, padahal penggunaan bahan sintetik mengakibatkan dampak yang tidak baik bagi sekitar contohnya menjadi limbah yang beracun, alergi kulit. Pewarna sintetik bersifat racun dan berefek samping bagi semua mahluk hidup Kant ( 2012:95 ). Sedangkan menggunakan bahan alami lebih ramah pada lingkungan dan tidak menimbulkan efek beracun seperti yang ditimbukan oleh bahan Sintetik. Oleh karena itu penggunaan pewarna alami digiatkan kembali di seluruh dunia Kant ( 2012:95 ).

Zat pewarna alam dapat diperoleh dengan cara ekstaksi dari berbagai bagian tanaman menggunakan pelarut air pada suhu tinggi atau rendah, pada suhu tinggi akan lebih cepat mendapatkan warna yang akan didapatkan akan tetapi jika dengan suhu yang rendah atau bahkan tanpa suhu akan lama mendapatkan warna yang diinginkan. Pada cara ini zat yang terambil sangat bervariasi tergantung dari jenis sumbernya. 


\section{Sabut Kelapa}

Kelapa merupakan tumbuhan asli daerah tropis, yakni daerah yang terletak di sepanjang Garis Katulistiwa. Di daerahdaerah tripis tersebut, tanaman kelapa banyak tumbuh dan dibudidayakan oleh sebagian besar petani. Tanaman kelapa sangat bermanfaat bagi kehidupan manusia sehari-hari. Tidak hanya buahnya, akan tetapi seluruh bagian dari kelapa memiliki manfaat bagi manusia.

Menurut Hartono (2013:3) “ kelapa adalah tanaman tropis yang dapat tumbuh mulai dari pantai hingga ketinggian 1.000 meter diatas permukaan laut. Tanaman kelapa tumbuh optimal pada 10 ` LS (lintang selatan) hingga 10 ' LU (lintang utara) dan masih tumbuh baik pada $15^{`} \mathrm{LS}$ dan 15 'LU”. Dalam bahasa Melayu, pohon kelapa juga dinamakan pokok seribu guna. Di Filipina pohon kelapa disebut The tree of life, artinya pohon kehidupan. Meurut angka statistik perkebunan pada tahun 2003, tanaman kelapa di Indonesia mencapai 3,88 juta hektar yang sebagian besar berupa perkebunan rakyat dengan luas 3,80 juta hektar atau 97,8\% yang melibatkan 7,7 juta KK petani.

Sepertiga berat butir kelapa terdiri dari atas serabut kelapa yang juga disebut Husk. Serat sabut kelapa termasuk serat kasar yang juga penting dalam perdagangan dunia. Negara penghasil serat sabut kelapa antar lain India, dengan produksi sekitar 140.000 ton, dan Srilanka, dengan produksi sekitar 120.00o ton, Warisno ( 2003:122 ).

Hartono (2013 : 19) "sabut kelapa merupakan bagian yang cukup besar dari buah kelapa, yaitu $35 \%$ dari berat keseluruhan buah". Setiap butir kelapa mengandung serat 525 gram (75\%) dan gabus 175 gram (25\%).

Hartono (2013:19) sabut kelapa menghasilkan serat yang dapat diolah menjadi beragam produk yang bernilai ekonomi. Tidak hanya itu, sabut kelapa juga bisa diolah menjadi pewarna alami untuk tekstil. Skla usaha bisa dilakukan dari rumah- rumah, sanggar, atau produksi yang lebih besar lagi.

Kandungan sabut kelapa disampaikan oleh,Setiawati, Dkk ( 2014 ) dengan demikian sabut kelapa mampu menghasilkan zat pewarna alam karena mengandung tanin dengan zat pewarna kuinon. Pada ekstrak sabut kelapa muda menghasilkan warna coklat muda sampai coklat tua sedangkan pada ekstrak sabut kelapa tua dapat menghasilkan warna coklat kemerahan.

\section{Batik}

Batik adalah seni dan cara menghias kain dengan penutup lilin atau malam untuk membentuk corak hiasan dan membentuk sebuah bidang pewarnaan. Warna dari batik sendiri dicelup dengan memakai zat warna.

Batik merupakan kerajinan yang memiliki nilai seni tinggi dan telah menjadi bagian dari budaya indonesia, khususnya masyarakat di jawa sejak zaman dahulu. Batik merupakan bahan kain yang digunakan untuk membuat pakaian, baik berupa baju maupun kain kebaya yang digunakan oleh kaum wanita. Saat ini batik sudah menjadi jenis kain yang dimanfaatkan secara luas oleh masyarakat Indonesia untuk seragam sekolah, seragam kantor, baik secara resmi, maupun acara-acara santai.

Batik di Indonesia sudah banyak berkembang seiring dengan perkembangan teknologi dan desain model. Namun perkembangan tersebut tidak menghilangkan ciri utama batik yang mempunyai nilai filosofi sangat mendalam, serta tidak menghilangkan keunikan batik sebagai kain yang cocok dikenakan semua orang.

Herry ( 2013:10 ) Jenis batik ada 3 cara menurut teknik pembuatannya, di mana pada setiap pembuatannya mempunyai karakteristik yang berbeda-beda, yakni Batik tulis, Batik cap dan batik lukis . 
MELAYYU ARTSAND JOURNAL

\section{HASIL DAN PEMBAHASAN}

Penelitian ini bertujuan untuk mengetahui bagaimana proses dan hasil warna apa saja yang akan, penelitian ini menghasilkan 12 karya denga ukuran $50 x 40$ cm dengan berat kain 200 gram yang dijadikan sebagai populasi dan sampel pada penelitian ini. Pembuatan batik tersebut dimuai dari mordanting, memindakan desain pada kain, pencantingan, pengekstakan bahan sabut kelapa, pencelupan warna dengan interval waktu, proses Fiksasi dan terakhir proses pelorodan.

\section{Mordanting}

Sebelum mengolah kain yang akan dijadikan batik, langkah pertama yang dilakukan adalah mordanting terlebih dahulu. Sebeb bisa dikatakan berhasil atau tidaknya hasil batik dengan menggunakan perwarna alam tersebut tergantung pada proses mordantingnya, maka dari itu proses mordanting dapat dilakukan dengan tepat dan tidak terlalu cepat

Untuk menghasilkan warna yang Stabil diperlukan bahan campuran lain yakni garam logam seperti tawas. Penggunaan mordanting dapat mengurangi kelunturan terhadap pengaruh pencucian, mengikat warna agar tidak mudah luntur dan menghasilkan kerataan pada kain dengan baik.

Takaran mordan dapat disesuikan dengan ukuran berat kain yang digunakan, pada kesempatan ini peneliti menggunakan barat timbangan kain 200 gram, berikut takaran mordannya :

a) Kain direndam dalam larutan deterjen selama semalaman 2 gram/ liter. Keesokan harinya kain dicuci bersih dan diperas.

b) Rebus air hingga mendidih sebanyak 8 liter yang mengandung zat campuran tawas 50 gram dan soda abu 15 gram, rebus selama 1 jam sambil di bolak-balik kainnya.

\section{Vol. 4, No. 1, April, 2021}

c) Setelah itu matikan apinya dan biarkan kain dalam larutan tersebut selama semalaman.

d) Kesokan harinya kain dicuci bersih dan dijemur diangin-anginkan saja sampai kering.

\section{Membatik}

Langkah selanjutnya adalah memindahkan desain pada kain, motif yang digunakan peneliti adalah perpaduan antara kaligrafi dan motif tumbuh-tumbuhan Flora. Motif kaligrafi ini diambil dari nama-nama Allah SWT atau sebutan lainnya juga yang sering didengar adalah $\mathrm{Al}$ Asmauh Husna sentara motif Flora pada batik hanyak sebagai pelangkap hisan saja.

Setelah itu mencanting adalah proses membuat batik tulis secara manual menggunakan bahan lilin (malam). Pencantingan lilin ini membuat pola yang sudah didesain sebelumnya dan fungsi dari pencantingan adalah menutup bagian yang ingin tidak terkena warna dengan kata lain lilin yang digoreskan sebagai peghalang warna. Lilin (malam) yang dicantingkan tidak bisa terlalu panas juga tidak bisa terlalu dingin walaupun masih terlihat encer, tinggkat kepenasan pada lilin adalah yang sedang saja, tidak terlalu panas dan juga tidak terlalu dingin.

\section{Pembuatan Warna Alami}

Proses pengekstarakan sabut kelapa hampir sama dengan proses pengekstarakan bahan alami lainnya yang digunakan untuk pembuatan warana alami batik. Pengekstakan dapat dilakukan mengunakan pelarut air dengan takaran yang pas. Dalam pembuatan larutan warna alam perlunya ada penyesuaian dengan bahan kain yang akan diberi warna dan banyak laruran hasil pengekstarakan warna, perbandingan yang digunakan peneliti 200 gram berat kain maka larutan warna yang dibutuhkan sebanyak 6 liter.

Langkah pengekstakan dilakukan dengan cara sebagai berikut :

a) Sabut kelapa tua dijemur terlebih dahulu yang masih basah hingga benar-benar kering. 
b) Pisahkan kulit keras luar sabut kelapa, kemudian ambil sabut kelapanya lalu timbang sebanyak $1,3 \mathrm{~kg}$.

c) Rebus sabut kelapa tersebut dengan 10 liter air selama kurang lebih 1 jam sambil dibolak-balik.

d) Setelah air rebusan tersisa 6 liter maka matikan kompornya, lalu biarkan dalam panci semalaman, dan keesokan harinya saring airnya dan sedikit diperas pada sabut kelapa karena sifatnya sabut kelapa menyerap air. Larutan warna siap digunakan.

\section{Pewarnaan}

Pencelupan warna dilakukan peneliti dengan beberapa cara yakni 5 jam, 10 jam, 15 jam dan celup berulang-ulang sampai 7 kali pencelupan. Proses pencelupannya sebagai berikut :

a) Kain batik direndam sampai merata terlebih dahulu dalam larutan TRO selama kurang lebih 30 menit, kemudian tiriskan.

b) Setelah setengah kering masukkan semua kain dalam larutan warna sambil di bolak-balik.

c) Angkat kain sesuai jadwal yang sudah dikehendaki yakni 5 jam, 10 jam, 15 jam dan pencelupan berulang-ulang, selama 7 kali pencelupan. Pencelupan yang berulang caranya adalah kelup kedalam larutan sambil dibolak balik hingga merata, kemudian angkat dan dijemur, dan setelah setengah kering celupkan kembali sambil di bolak-balik sampai berata kemudian dijemur kembali, begitulah kain tersebut dicelupkan sampai 7 kali pencelupan.

d) Pada semua tekni pencelupan baik 5 jam, 10 jam, 15 jam dan yang dicelup berulang-ulang proses penjemurannya hanya dianginanginkan saja.

\section{Fiksasi}

Fiksasi berfungsi sebagai memperkuat warna atau lebih dikenal dengan pengunci warna dan pengolahan Fiksasi dapat dilarutkan dengan direbus sampai setiap Fiksasi larut. Takaran air pada setiap Fiksasi sebagai berikut :
a) Tawas 70 gram/ liter air, setalah itu diamkan semalaman kemudian ambil larutan beningnya saja.
b) Kapur 50 gram/ liter air, setalah itu diamkan semalaman kemudian ambil larutan beningnya saja.
c) Tunjung 20 gram/ liter air, setalah itu diamkan semalaman kemudian ambil larutan beningnya saja.

Cara pencelupannya dengan Fiksasi

a) Ambil kain kering yang sudah melalui proses dicelup dengan warna.

b) Ambil 3 lembar kain yang dicelupkan dalam waktu 5 jam dan celupkan 1 lembar kain pada setiap Fiksasi tawas, Fiksasi kapur, Fiksasi tunjung. Kemudian keringkan dengan dianginanginkan.

c) Ambil 3 lembar kain yang dicelupkan dalam waktu 10 jam dan celupkan 1 lembar kain pada setiap Fiksasi tawas, Fiksasi kapur, Fiksasi tunjung. Kemudian keringkan dengan dianginanginkan.

d) Ambil 3 lembar kain yang dicelupkan dalam waktu 15 jam dan celupkan 1 lembar kain pada setiap Fiksasi tawas, Fiksasi kapur, Fiksasi tunjung. Kemudian keringkan dengan dianginanginkan.

e) Ambil 3 lembar kain terakhir yang dicelupkan dengan pencelupan berulang-ulang dan celupkan 1 lembar kain pada setiap Fiksasi tawas, Fiksasi kapur, Fiksasi 
tunjung. Kemudian keringkan dengan diangin-anginkan.

\section{Pelorodan}

Pelorodan merupakan tahapan terakhir dari keseluruhan proses pembuatan batik, tujuan dari pelorodan adalah mengilangkan lilin malam yang menempel pada kain, yang sudah di canting maupun dicetak.

Takaran bahan yang diperlukan untuk melorod yakni 70 gram soda abu/ liter air, langkah perorodannya sebagai berikut :

a) Masukkan air dalam panci sesuai yang dibutuhkan.

b) Sediakan 2 ember berisi air bersih untuk mencuci kain yang sudah dilorod

c) Setelah mulai mendidih masukkan soda abu sesuai air yang sudah dimasukkan, naik turunkan kain dengan bantuan alat kayu, agar lilinnya turun atau lorod.

d) Cuci bersih kain yang sudah dilorod pada ember cucian pertama kemudian cuci kembali pada ember kedua, hingga lilin malam benar-benar hilang atau lorod.

e) Jemur kain ditempat yang tidak terkena matahari dengan diangin-

\section{Hasil} anginkan saja.

Pada hasil ini peneliti mengambil sampel 3 dari 12 karya yang sudah diteliti, karena hasilnya dapat diwakilkan dari ketiga karya tersebut yakni pada karya 1, 7 dan 12.

a) Karya 1

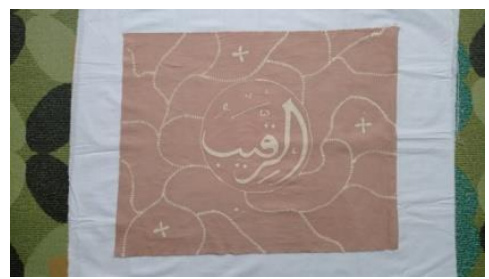

Gambar 1 . Karya Batik Kaligrafi ( Foto : Yogi Setiawan, 2020 )
Karya 1 dengan ukuran $50 x 40 \mathrm{~cm}$ merupakan karya batik kaligrafi dengan tambahan corak hisan Flora disekeliling kaligrafi tersebut, tulisan kaligrafi tersebut bertulisan Ar-Raqiib artinya yang maha mengawasi, Dialah yang melihat segalanya, selalu. Pengwasan setiap detil dalam keberadaan makhlukNya adalah bagian dari perlindunganNya. Kemudian pada bagian luar kaligrafi tersebut merupakan hiasan Flora tumbuh-tumbuhan yakni tumbuhan yang berduri.

Proses pembuatan batik ini bersamaan dengan pembuatan karya lainnya. Hasil pewarnaan batik berfariasi jika menggunakan Fiksasi yang berbeda, karya 1 ini peneliti melihat dari 4 sisi penilaian yakni, kecerahan, kerataan, berdasarkan penguncinya dan berdasarkan waktunya. Jika dilihat dari kecarahan dari karya 1 ini memiliki kecerahan cukup muda dari yang lainnya dalam golongan coklat muda terang, ini disebabkan karena pada pewarna alami tidak memiliki kecerahan seperti kita menggunakan bahan pewarna sintetis, warnanya terlihat pudar akan tetapi terlihat lembut.

Kemudian pada kerataannya secara keseluruhan sudah sangat baik, warnanya juga tidak ada yang bercak-bercak tumpukan warna yang pekat ataupun lebih pudar. Kita semua tau setiap individu memiliki selera warna yang berbeda-beda dan pada karya 1 ini cocok untuk dijadikan alternatif pengganti warna coklat terang, karena warnanya bagus.

Selanjutnya berdasarkan waktu pada karya 1 ini dengan waktu selama 5 jam perendaman didalam larutan warna, yang menjadi salah satu faktor warna yang didapatkan pada hasil akhir lebih terang atau lebih gelap. Dan yang terakhir pengunci yang digunakan adalah Fiksasi tawas yang kandungannya adalah Aluminium Kalium Sulfat merupakan bahan kimia yang tidak beracun, jadi aman untuk digunakan. 


\section{b) Karya 7}

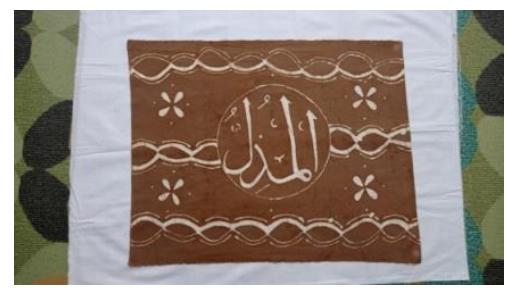

Gambar 2 . Karya Batik Kaligrafi ( Foto : Yogi Setiawan, 2020 )

Karya 7 batik kaligrafi bertulisan AlMuzil artinya yang maha menghinakan, Dialah yang maha menghinakan. Dengan ukuran karya $50 \times 40 \mathrm{~cm}$, merupakan karya batik tulis kaligrafi dengan tambahan corak hisan Flora disekeliling kaligrafi tersebut, Kemudian pada bagian luar kaligrafi tersebut merupakan hiasan Flora tumbuh-tumbuhan yakni tumbuhan dengan bunga dan pohon yang melilit.

Hasil pewarnaan batik ini memiliki kecerahan colat tua, padahal durasi waktu yang digunakan selama 15 jam dan hasilnya sama dengan karya 6 dengan durasi waktu 10 jam.

Penilaian pada kecerahan, kerataan, berdasarkan penguncinya dan berdasarkan waktunya, hasilnya sama dengan karya yang sebelumnya memiliki kecerahan colat tua dan kecerahannya cukup bagus, walaupun tidak memiliki kecerahan pada umumnya seperti kita menggunakan bahan pewarna sintetis yang mana warnanya terlihat pudar jika menggunakan bahan alami dan terang jika menggunakan bahan pewarna sintetis.

Kerataannya tidak bagus karena ada bercakbercak yang terlihat cukup banyak, penggunaan pengunci yang salah atau pada proses yang lainnya yang salah membuat peneliti sedikit heran dan binggung kenapa hal tersebut terjadi, pada saat pelorodan peneliti tidak melihat ada yang salah bahkan terlihat bagus dan rata, akantetapi setelah hampir kering barulah terlihat bercak-bercak yang banyak. Awalnya peneliti mengira bercak-bercak tersebut adalah lilin Malam yang belum lorod, lalu peneliti merebusnya kembali untuk melorodnya kembali yang kedua kalinya, dan hasilnya warnanya semakin pudar dan bercaknya hanyak sedikit yang berkurang.

Yang terakhir pada pengunci yang digunakan adalah Fiksasi tunjung yang kandungannya adalah Kalium Bikromat zat yang dapat merubah warna hasil setelah dicelup menjadi lebih gelap dari sebelumnya.

c) Karya 12

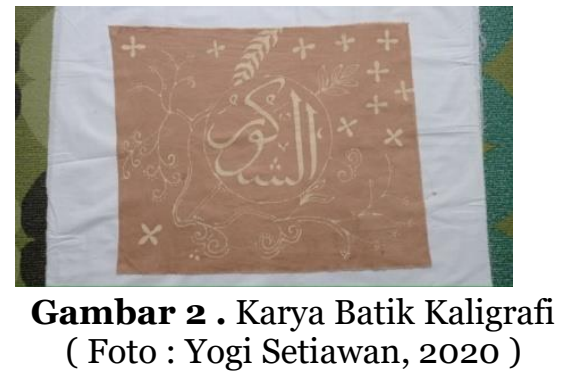

Karya 12 merupakan karya batik kaligrafi ukuran $50 \times 40 \mathrm{~cm}$ dengan tambahan corak hisan Flora disekeliling kaligrafi tersebut, tulisan kaligrafi tersebut bertulisan Asy-Syakuur artinya yang maha pembalas budi, Dialah yang membalas perbuatan baik dengan ganjaran yang lebih besar. Syukur adalah pembalas yang baik dengan yang baik. Setelah itu pada bagian luar kaligrafi tersebut merupakan hiasan Flora tumbuh-tumbuhan yakni tumbuhan berdaun dan bunga.

Hasil pewarnaan batik ini memiliki kecerahan colat muda kekuningan dengan teknik pencelupan sebanyak 7 kali, masudnya setelah dicelup sambil dibolak-balik langsung dijemur diangin-anginkan dan setelah setengah kering celup kembali sambil dibolak balik begitulah seterusnya sampai 7 kali pencelupan. Hasil sama dengan pencelupan 15 jam, sebeb pewarna alami tidak memiliki kecerahan seperti kita menggunakan bahan pewarna sintetis yang mana warnanya terlihat pudar jika menggunakan bahan alami.

Hasil pewarnaan batik berfariasi jika menggunakan Fiksasi yang berbeda, karya 12 ini peneliti melihat dari 4 sisi penilaian yakni, kecerahan, kerataan, berdasarkan penguncinya dan berdasarkan waktunya. Pada kerataannya secara keseluruhan sudah sangat baik, warnanya juga tidak ada yang bercakbercak tumpukan warna yang pekat ataupun 
lebih pudar. Pada karya 12 ini cocok untuk dijadikan alternatif pengganti warna coklat muda kekuningan, karena warnanya bagus dan rata.

Perendaman didalam larutan warna menjadi salah satu faktor yang akan didapatkan pada hasil akhir lebih terang atau lebih gelap, untuk pengunci yang digunakan adalah Fiksasi kapur yang kandungannya membuat warnanya mempertahankan warna dari hasil pencelupannya dan juga dapat membuat warna lebih tua sedikit dari hasil warna pencelupannya.

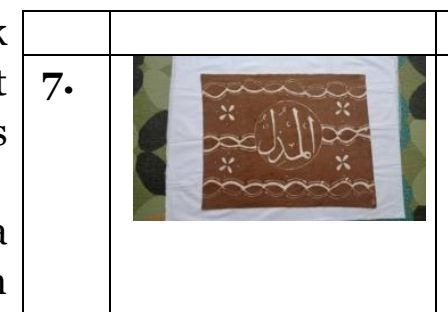

$\begin{array}{|ll|} & \\ \text { Tunjung } & \text { dan } \\ 15 & \text { jam } \\ \text { perendaman } \\ \text { dalam } & \text { larutan } \\ \text { warna } & \\ & \end{array}$

coklat tua

8.

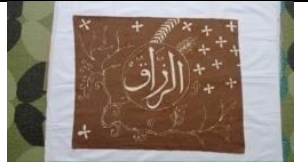

9.

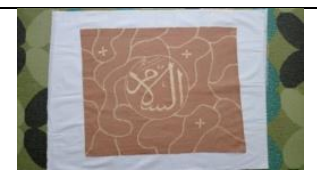

Tunjung dan Ukuran

Celup jemur 50x40,

\begin{tabular}{l|l} 
kering & Warna
\end{tabular}

\begin{tabular}{ll|l} 
sebanyak $\quad 7$ & yang
\end{tabular}

kali dihasilkan

pencelupan coklat tua

Kapur dan 15 Ukuran

jam

perendaman Warna

dalam larutan yang

warna

dihasilkan

adalah

coklat

kekuninga

Perendaman

\begin{tabular}{|l|l|}
\hline 1. & \\
&
\end{tabular}

Tawas dan 5 Ukuran

jam

perendaman

dalam larutan

warna

50x40, 10

Warnanya

coklat

muda

terang

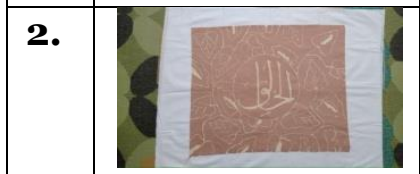

Tawas dan 10

jam

perendaman

dalam larutan

warna

Ukuran

$50 \times 40$,

Warnanya

coklat

muda

terang

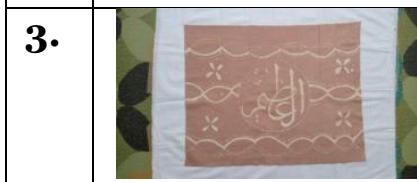

Tawas dan 15

jam

perendaman

dalam larutan

warna

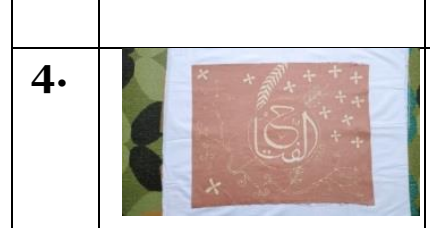

Tawas dan

Ukuran

50x40,

Warnanya

coklat

muda

terang

11

Celup jemur

kering

sebanyak 7

kali

pencelupan

Ukuran

$50 \times 40$,

Warnanya

coklat

muda

terang

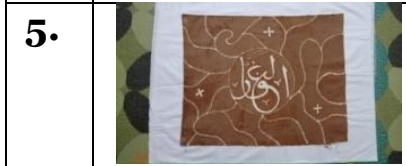

Tunjung dan 5

jam

perendaman

dalam larutan

warna

Ukuran

$50 \times 40$,

Warna

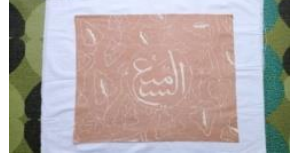

Kapur dan 15

jam

perendaman

dalam larutan

warna

$\mathrm{n}$

Ukuran

$50 \times 40 \mathrm{~cm}$,

Warna

yang

didapat

adalah

coklat

kekuninga

$\mathrm{n}$, yang

menjadi

warna

termuda

dari yang

lainnya

Kapur dan 15 Ukuran

jam

perendaman

$50 \times 40 \mathrm{~cm}$,

dalam larutan yang

warna

dihasilkan

adalah

coklat

kekuninga

$\mathrm{n}$

yang

dihasilkan

coklat tua

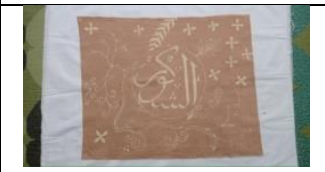

Kapur dan Ukuran

Celup jemur $50 \times 40 \mathrm{~cm}$,

kering

kali

pencelupan

dihasilkan

adalah

coklat

kekuninga

$\mathrm{n}$

perendaman

50x40,

Warna

dalam larutan

warna

yang

dihasilkan 


\section{KESIMPULAN}

Berdasarkan hasil penelitian pada proses pengolahan ekstrak sabut kelapa sampai pada hasil warna yang didapatkan di Sanggar Seni Pendopo, diperoleh beberapa kesimpulan dan saran sebagai berikut :

Proses pembuatan warna menggunakan bahan alam menjadi warna alami memiliki proses yang cukup panjang dibandingkan dengan proses pembuatan batik dengan bahan sintesis yang lebih cepat pembuatannya. Mulai dari proses mordanting, proes pencantingan, proses pengolahan warna alam, proses pencelupan, proses penguncian menggunakan Fiksasi tawas, Fiksasi tunjung dan Fiksasi kapur, proses pelorodan dan itu semua harus dilakukan dengan teliti dan benar.

Waktu yang digunakan terbagi menjadi 4 golongan yakni 5 jam, 10 jam, 15 jam dan yang dicelup kering berulang-ulang sebanyak 7 kali pencelupan. Yang mana hasilnya tidak begitu berpengaruh pada hasil yang didapatkan. Sebeb dari 4 golongan waktu tersebut hanya menjadi dua golongan hasil yakni 5 jam menjadi gologan tersendiri dan 10 jam, 15 jam, dan yang dicelup kering berulang-ulang sebanyak 7 kali pencelupan menjadi satu golongan lainnya. Peneliti menyimpulkan jika kain direndam dalam larutan warna 10 jam keatas itu akan menjadi hasil yang sama saja .

Secara umumnya warna yang dihasilkan Fiksasi tawas akan menjadi warna yang lebih muda dari warna aslinya setelah pencelupan. Kemudian warna yang dihasilkan Fiksasi tunjung akan menghasilkan warna paling gelap juga pekat dan warna yang dihasilkan dari Fiksasi kapur akan menghasilkan warna yang sama akan tetapi memberikan tambahan warna kekuningan pada kain dan juga dapat naik menjadi warna yang lebih gelap sedikit dari warna aslinya setelah melui proses pencelupan warna.

Pengolahan sabut kelapa sebagai warna alami dapat dijadikan sebagai pilihan sebab lebih ramah akan lingkungan. Dan lebihnya lagi setiap penunci dapat menghasilkan warna yang berbeda-beda. warna yang dihasilkan dari ekstrak sabut kelapa adalah pada Fiksasi tawas menjadi warna coklat terang, kemudian pada Fiksasi tunjung menjadi coklat tua dan pada Fiksasi kapur menjadi coklat kekuningan.

Fiksasi yang digunakan memberikan efek yang berbeda pada tingkat kerataan kain, pada Fiksasi tawas dan Fiksasi kapur akan menghasilkan warna yang rata dan sudah sanagat baik dan cocok untuk dijadikan alternatif warna lain, warnanya juga tidak ada yang bercak-bercak tumpukan warna yang pekat ataupun lebih pudar. Sementara pada Fiksasi tunjung kerataannya tidak bagus karena masih ada bercak-bercak yang terlihat cukup banyak.

\section{DAFTAR PUSTAKA}

Fitriah, Hidayatul Dan Fajar Ciptandi, “ Pengolahan Limbah Sabut Kelapa Tua Sebagai Pewarna Alam Pada Fesyen", Jurnal E-Proceeding Of Art \& Desaign, Vol.5, No.3 Desember 2018,2537.

Hartono, Edi Tri, 2013. Mengolah Sabut Kelapa. Yogyakarta : Arcita

Kina, 2013. Batik Nusantara Batik Of The Archipelago. Jakarta : Pusat Komunikasi Publik

Lestari, Suaerna Dwi. 2012. Mengenal Aneka Batik , Jakarta Timur:Pt Balai Pustaka.

Lisbijanto, Herry. 2013. Batik. Yogyakarta: Graha Ilmu.

Warisno, 2003. Budi Daya Kelapa Genjah. Yogyakarta: Kanisius. 